\title{
The Impact of Audit Committee on Financial Performance of Insurance Firms in Nigeria
}

\author{
Araoye F. Ebun, (PhD, FCA, ACIT) \\ Audit Department, Ladoke Akintola University of Technology, Ogbomoso, Oyo State, Nigeria
}

\begin{abstract}
This study examined the effect of audit committee size on the financial performance of insurance companies in Nigeria between the year 2004 and 2015. The study used secondary data obtained from the annual report, National Insurance Commission Facts Books and Nigeria Stock Exchange Facts Books of fifteen selected insurance companies listed on the Nigeria stock exchange. The collected data were analyzed using descriptive statistics and regression analysis. The result revealed a significant negative correlation between audit committee and financial performance. The study recommended that the regulatory authorities focus more on other appropriate measure like competence (financial expert in committee) and independence of the committee that will ensure check and balance framework in the audit exercise and hence positive performance.
\end{abstract}

Keywords: Audit Committee, Financial Performance, Insurance companies, Nigeria

DOI: $10.7176 /$ RJFA/10-14-02

Publication date:July $31^{\text {st }} 2019$

\subsection{Introduction}

Historically, audit activities dates back to the ancient days when the land owners allowed tenant farmers to work on their field while the owners were not participating in the farming venture. The land owner relied mainly on overseers who listen to the account of stewardship given by the tenants Olowookere (2014). In the modern commercial environment, it is important that entities that operates as companies with limited liability should produce accounts which will indicate how successful they are performing. Audit is very important if any organization strive to attain laudable objective of financial prosperity. The audit has been specifically described as 'the independent examination of, and expression of opinion on, the financial statements of an enterprise by an appointed auditor in pursuance of that appointment and in compliance with any relevant statutory obligation. Section 359, (3\&4) of Companies and Allied Matters Act of 1990 recommends the existence of an audit committee with not more than six members, and not more than one member as executive director. The Chairman should be a non-executive director and the committee is expected to meet at least three times a year. In addition to his report to the member's, the auditor of a public company is required to render a report to the company's audit committee. Carcello, Hermanson, Neal and Riley (2002) study discovered a gap between what audit committees say they are doing and what their charter mandated. Even though this gap may be due to numerous reasons including liability concerns, it raises the general issue of transparency and accountability with respect to activities of the audit committee. The committee is to look at the accounting and reporting policies to ensure its compliance to legal requirement and ethical procedure. The committee is expected to resolve every audit logjam that may arise from both interim and final audit report with the management and ensure necessary compliance to recommendations stated in the report.

The contents of the auditor's report derive from the functions and objectives of the audit committee, which are discussed below.

\subsection{Statement of Problems}

The audit committee is established to provide a body of people who are independent of management and to which the external auditor can relate with and should be able to resolve problems that could arise in the management of an entity. The committee is expected to be in a position of deterrent to executive directors that carries on unlawful acts that are not in the interest of the stakeholders. However, in order to carry out its responsibilities and add positively to effective internal control and prevent corporate governance failure, the appropriate constitution of the committee is required. Bédard, Chtourou and Courteou (2004), argue that the larger the audit committee is more likely to discover and resolve likely problems in the financial reporting process. However, small audit committees that is not large enough e.g with one or two members could be regarded as weak because it will be easy for management to exert pressure on them to gain its support when there is any dispute with the auditor. It may be difficult to obtain sufficient numbers of non-executive directors in a company with a good appreciation of the auditor's work to constitute the audit committee. Most corporate failure in Nigeria has been attributed to ineffective and inefficient audit committee (Ebere \& Ibanichka, 2016). This therefore shows the importance of audit committee in corporate performance of organizations. Study relating to importance of Audit Committee independence was conducted by DeZoort and Salterio (2001) with the result revealing greater support for auditor in an accounting dispute case with increased independent director experience and audit knowledge using 68 audit 
committees in their sample.

\subsection{Objective of the Study}

The objective of this study is to establish the impact of audit committee on financial performance of insurance companies in Nigeria.

\subsection{Theoretical Framework \\ 2.0.1 The Agency Theory}

The agency theory of corporate governance which was developed by Jensen and Meckling in 1976, sees shareholders as the principals and management as their agents. They confirm that agents will love to maximize their monetary reward, job stability and other perks, and they will do no more than seek to pacify the shareholders. Nonetheless, there is a need to strictly monitor their activities so as to ensure that their principal's best interests are served. This theory is the anchor of today's corporate governance activity.

Corporate governance focused on separation of ownership and control which results in principal-agent problems arising from the dispersed ownership in the modern corporation (Berle \& Means 1932). They viewed corporate governance as a device where a board of director is essentially a monitoring mechanism to maximize the problems brought about by principal agency connection. Mallin (2004), explained in this context that agents are managers, principal are owners and board of directors are monitoring device. Many researchers have examined the board composition due to the importance of the monitoring and governance function of the board (Barnhart, Mar \& Rosentein 1994: Pearce \& Zahra 1992: Gales \& Kesner 1994). They confirm that agency theory considers that the primary responsibility of board of directors is towards the shareholders to ensure maximization of their wealth.

\subsubsection{The Stewardship Theory}

This was propounded by Donaldson and Davis in 1991. The theory states that, since people can be allowed and trusted to act in the public good in general and the interest of their shareholders in particular, it will be necessary to create operational and authority structures. This will provide unified command and facilitate autonomous decision making, enable companies to act (and react) quickly and decisively to market opportunities. According to this theory, managers represented by the board of directors are considered a good stewardship that will actually act in the best interest of owners. Donaldson and davis (1991), observe a strong connection between managers and firm good performance thereby protecting and optimizing the shareholders value. It is expected that acting in the best interest of the owner will lead to firm success.

\subsubsection{The Stakeholders Theory}

This was developed by Freeman in 1984 with belief that accountability should be made to the stakeholders instead of only shareholders. "The firm" is a system of stake holders operating within the larger system of the host society that provides the necessary legal and market infrastructure for the firm's activities. The purpose of the firms is to create wealth or value for its stake holders by converting their stakes into goods and services. World Business Council for Sustainable Development identified stakeholders as the representative from labour organization, academia, church, indigenous people, government, non-government organization, customers/consumers, communities, employees, legislators and human right groups. Narrow attention on shareholders by the board of directors has now been increased to the stakeholders interest (Smallman, 2004). This, perhaps account for reason why royal fathers, labour movement, academia e.t.c in Nigeria are represented and feature prominently in board composition of many organizations.

\subsubsection{The Signalling Theory}

This theory on corporate disclosure considered information asymmetry very important for better performance. According to the theory, any organization that could provide reliable information with transparency will definitely signal better corporate governance performance. Chiang, (2005) confirm that organizations that operates better corporate governance signal better performance. Spence (1973) affirmed that a company can reduce or remove the information asymmetry by providing information to various investors. The existence of information asymmetry creates a misunderstanding of the company's operation or dealings by the investors which may hamper their reliance in making investment decision (Poitevin, 1990; Ravid \& Saring, 1991).

\subsection{Empirical Review}

\subsubsection{Audit Committee Size and Firm Performance}

Studies, carried out by Lipton and Lorsch (1992), Jensen (1993) and Yermack (1996), noticed that the number of members on an audit committee actually have effects on its decisions. Bédard, Chtourou and Courteou (2004), argue that the larger the audit committee is more likely to discover and resolve likely problems in the financial reporting process. This is because of the strength and divergent of views with different expertise they possess which would ensure effective monitoring. Furthermore, Chen and Zhou (2007) study find that firms with a bigger audit committee, due to reputation mostly assign the Big 4 auditors for audit engagement. Braiotta (2006) argue 
for a large size audit committee members with a diverse professional judgment and experience but not to unmanageable size. However, small audit committees that is not large enough e.g with one or two members could be regarded as weak because it will be easy for management to exert pressure on them to gain its support when there is any dispute with the auditor.. Empirical studies show mixed result on the effect of audit committee size on performance. Xie, Davidson and DaDalt (2003) and Bédard et al. (2004) find no significant association between audit committee size, measured by the number of directors on the committee, and performance management. This is also supported by the study of Abbott, Park and Parker (2004), which find negative relationship between audit committee size and reporting quality. However, Abdul Rahman and Ali (2006) study the extent of the effectiveness of the audit committee size in reducing earnings management of Malaysian quoted companies. Their study reveals positive association between audit committee size and performance management. This indicates that a certain minimum number of audit committee members may be vital to firm performance.

\subsubsection{Audit Committee and Corporate Governance Disclosure}

Carcello et al. (2002) study found gap between what audit committees say they are doing and what their charter mandated. Even though this gap may be due to numerous reasons including liability concerns, it raises the general issue of transparency and accountability with respect to activities of the audit committee.

Study relating to importance of Audit Committee independence was conducted by DeZoort and Salterio (2001) with the result revealing greater support for auditor in an accounting dispute case with increased independent director experience and audit knowledge using 68 audit committees in their sample. They found out that there is no affect for level of accounting knowledge.

DeZoort and Salterio (2001) examined the effects of Independence director experience; audit knowledge on Support for management or auditor and discovered that there is a better support for auditor in an accounting disputes situation with increased independent director experience and audit knowledge. The latter finding may have been due to the non-technical, generic nature of the accounting issue at hand. Audit Committee's may be firmed primarily for cosmetic reasons to make it appear to outside stakeholders that the company desires monitoring of financial reporting and controls.

Fogarty and Kalbers (1998), using data from their earlier study in 1993 discovered weakness association between Agency Theory factors and Audit Committee effectiveness. Collier and Gregory (1999) used 142 UK companies listed on the London Stock Exchange with result showing little support for the findings of Menon and Williams (1994) that confirm positive relationship between the Big 6 and leverage and Audit Committee activity.

Survey of Haka and Chalos (1990) concluded that Audit committee chairs are consistently different from other groups on what should constitute full disclosure (with audit committee members wanting greater disclosure). Krishnamoorthy (2002), established in their investigation that it is important to distinguish between the "form" (meeting regulatory requirements) and the "substance," (the effectiveness) of audit committees. Management exerts a significant influence over the quality of the interactions between the audit committee and the external auditor..

Dechow, Sloan and Sweeney (1996), result shows that firms subject to AAERs (accounting and auditing enforcement releases) are more likely to influence earnings to achieve lower cost of external financing. Beasley (1996) study evaluates the effect of corporate governance mechanism on fraud and discovered that larger percentage of outside members on board reduces fraud likelihood.

In their subsequent study, Beasley, Carcello, Hermanson and Lapides (2000), found that fraud companies in all 3 industries studied are less likely to have independent audit committees, outsiders on the board and to have an internal audit function.

Abbott et al. (2000) was able to conclude that Independence together with activity of the Audit Committee is associated with a lower incidence of AAER. Klein (2002) report of studies carried out on corporate governance mechanism and abnormal accrual in the books established negative relationship between board/audit committee independence and abnormal accruals. In their subsequent study, Abbott et.al. (2000) findings reveals that misstatement is affected by presence of a completely independent audit committee holding a minimum number of meetings while not significant are expertise and Characteristics of the Board of Directors . Wild (1996), result suggest that the audit committees provide a useful oversight mechanism for the financial reporting process and that this increased oversight results in improved earnings quality.

Abbott and Parker (2000) study concluded that Audit committees that are both independent and active are positively associated with selection of an industry specialist. Beasley and Petroni (2001) in their survey examining the percentage of outside directors on the board of 165 firms confirm that the likelihood that a specialist Big- 6 auditor is selected increases with the percentage of outside directors on the board, but the outside board membership percentage has no impact on the choice between a non specialist Big- 6 and non Big- 6 Auditor.

\subsection{Research Methodology}

\subsubsection{Study Population and sample}

The population for this study consists of all the 35 insurance companies listed on the floor of Nigeria stock 
exchange market out of which purposive sample was used in selecting the fifteen (15) listed insurance companies. These insurance companies were chosen because of their consistency on stock exchange market listing during the period of the study.

\subsubsection{Data Gathering Method}

Secondary data derived from the annual report of the insurance companies listed in the Nigerian Stock Exchange (NSE) during the twelve years period of 2004 and 2015 was used for the study with other related materials particularly the National Insurance Commission (NAICOM) and the Nigerian Stock Exchange database and Fact Books.

\subsubsection{Model Specification}

This study employed a modified version of the econometric model of Ntim and Ossei (2006).

These models are as follows;

MODEL 1 Relationship between audit committee and ROE

$$
R O E_{i t}=\alpha_{0}+\beta_{1} \text { AUDCOM }_{i t-1}+\sum_{i=1}^{n} \beta_{i} \text { CONTROLS }_{i t-1}+\varepsilon_{i t-1}
$$

MODEL 2 Relationship between audit committee and ROA

$R O A_{i t}=\alpha_{0}+\beta_{1} A_{U D C O M}+\sum_{i t-1}^{n} \beta_{i}$ CONTROLS $S_{i t-1}+\varepsilon_{i t-1}$

MODEL 3 Relationship between audit committee and Tobin's Q

$$
T Q_{i t}=\alpha_{0}+\beta_{1} A_{U D C O M}+\sum_{i t-1}^{n} \beta_{i=1} \text { CONTROLS } S_{i t-1}+\varepsilon_{i t-1}
$$

Where:

ROE, ROA and TQ are the main dependent variables; AUDCOM is the main explanatory variable. CONTROLS refer to the control variables, including $\mathrm{BOS}_{\mathrm{t}}, \mathrm{DEI}_{\mathrm{t}}, \mathrm{CGDI}_{\mathrm{t}}$, and $\mathrm{BACT}$.

Dependent variables

$\mathrm{ROE}=$ Return on Equity

$\mathrm{ROA}=$ Return on Asset

TQ = Tobin's Q

Independent variables

BACT $=$ Board Activism

BOS= Board Structure

DEI $=$ Directors' Equity Interest

CGDI $=$ Corporate Governance Disclosure Index

AUDCOM = Audit Committee

$e_{t},=$ Error Term

The a priori expectation is such that:

$\mathrm{BACT}_{t} \mathrm{BOS}_{t}, \mathrm{DEI}_{t}, \mathrm{CGDI}_{t}$, and $\mathrm{AUDCOM}_{t}>0$. A positive relationship is expected between explanatory variables $\left(\mathrm{BOS}_{t}, \mathrm{DEI}_{\mathrm{t}}, \mathrm{CGDI}_{\mathrm{t}}, \mathrm{AUDCOM}_{\mathrm{t}}\right.$ and $\left.\mathrm{BACT}_{\mathrm{t}}\right)$ and the dependent variables (ROE, ROA and Tobin's Q). The correlation coefficient $\left(\beta_{\mathrm{o}}\right)$ will help explaining the various levels of association between the independent variables.

\subsubsection{Descriptions of Variables and Measurement}

The variables used in the model are as described and measured below:

$\mathrm{ROA}=$ Return On Asset. This is measured as the ratio of Earning Before Interest and Tax (EBIT) to Total Asset.

$\mathrm{ROE}=$ Return on Equity. This is measured as the ratio of Earning Before Interest and Tax (EBIT) to Ordinary Shares.

Tobin's Q = Market Value of Equity + Total Debt/Total Assets

$\mathrm{BACT}=$ Number of board meetings held during a financial year

BOS $=$ Proportion of outside directors sitting on the board.

DEI $=$ Directors ordinary shares as a percentage of total outstanding shares of the firm

CGDI = Ratio of total score of the Individual company to maximum Possible score obtainable by company.

AUDCOM = Number of member in the committee.

\subsubsection{Data Analysis Method}

Panel data regression analysis methodology that combined time series and cross sectional data was used to measure the degree of association between disclosure and performance 


\subsection{Data Analysis}

\subsubsection{Descriptive Analysis}

This section presents summary of the descriptive characteristics of all variables used in the study. Statistics reported under this section include mean, standard deviation, minimum and maximum of the pooled observations of all variables across unit and time period i.e 15 insurance companies over 12 years period spanning from 2004 to 2015 . Summary of the descriptive statistics is presented in table 4.1 below:

Table 4.1

Descriptive Statistics

\begin{tabular}{|c|c|c|c|c|c|}
\hline Variable & Obs & Mean & Std. Dev. & Min & Max \\
\hline roe & 180 & 0.27 & 0.4677 & -1.41 & 2.78 \\
\hline roa & 180 & 0.066 & 0.16 & -7.93 & 1.099 \\
\hline tq $\mid$ & 180 & 1.10 & 0.749 & 0.266 & 4.888 \\
\hline bos & 180 & 0.719 & 0.1151 & 0.40 & 0.90 \\
\hline dei $\mid$ & 180 & 0.2193 & 0.119 & 0.008 & 0.46 \\
\hline cgdi $\mid$ & 180 & 0.725 & 0.695 & 0.30 & 0.92 \\
\hline audcom | & 180 & 0.94 & 0.138 & 0.67 & 1.00 \\
\hline bact & 180 & 0.933 & 0.11 & 0.75 & 1.00 \\
\hline
\end{tabular}

Source: Author's Computation (2018)

Table 4.1 report the average values of all the variables both dependent and independent alike. The table above reported average value of $27 \%$ for return on equity, $6.5 \%$ for return on asset, $110 \%$ for Tobin's Q. Given the reported average values of the three dependent variables it stands that across the 15 insurance companies sampled in the study over the period of 12 years spanning from 2004 to 2015, the average ratio of earnings before interest rate to ordinary share (return on equity) is $27 \%$, average ratio of earnings before interest and tax to total asset (return on asset) is $6.5 \%$ while the average ratio of the sum of market value of equity and total debt to total asset stood at $110 \%$. As reported in table 4.1 the average value of AUDCOM size was $94 \%$. The reported means value of audit committee revealed that the average audit committee for the sampled insurance companies over the period understudied stood at 94\% in size using the Company and allied matter decree of 1990 as amended of maximum of 6 members for a guide. The standard deviation stood at $13.9 \%$ which is a reflection of the average dispersion of the distribution of the distribution of observations corresponding to each of the variables from the centre. The minimum and maximum return on equity (ROE) across cross sectional unit over the period covered in the study stood at $-141 \%$ and $278 \%$. For return on asset (ROA) the minimum and maximum values stood at $-79.13 \%$ and $109.9 \%$, while for Tobin's Q the minimum and maximum statistics stood at $26.56 \%$ and $488.8 \%$ respectively. The reported minimum and maximum values of audit committee stood at $67 \%$ and $100 \%$. 


\subsection{Regression Analysis}

Table 4.2 Regression Analysis for model 1

Dependent Variable: ROE

Method: Panel Least Squares

Date: 04/04/18 Time: $16: 46$

Sample: 20042015

Periods included: 12

Cross-sections included: 15

Total panel (balanced) observations: 180

\begin{tabular}{|c|c|c|c|c|}
\hline Variable & Coefficient & Std. Error & t-Statistic & Prob. \\
\hline AUDCOM & -1.228820 & 0.495167 & -2.481628 & 0.0141 \\
\hline BACT & -1.078711 & 0.853915 & -1.263254 & 0.2083 \\
\hline BOS & -0.629518 & 0.333995 & -1.884812 & 0.0613 \\
\hline CGDI & -0.032318 & 0.014182 & -2.278763 & 0.0240 \\
\hline DEI & 0.217282 & 0.377767 & 0.575173 & 0.5660 \\
\hline $\mathrm{C}$ & 285.6675 & 123.2125 & 2.318495 & 0.0217 \\
\hline \multicolumn{5}{|c|}{ Effects Specification } \\
\hline \multicolumn{5}{|c|}{ Cross-section fixed (dummy variables) } \\
\hline R-squared & 0.260470 & \multirow{7}{*}{\multicolumn{2}{|c|}{$\begin{array}{l}\text { Mean dependent var } \\
\text { S.D. dependent var } \\
\text { Akaike info criterion } \\
\text { Schwarz criterion } \\
\text { Hannan-Quinn criter. } \\
\text { Durbin-Watson stat }\end{array}$}} & 26.56650 \\
\hline Adjusted R-squared & 0.172651 & & & 46.79982 \\
\hline S.E. of regression & 42.56853 & & & 10.44455 \\
\hline Sum squared resid & 289932.8 & & & 10.79932 \\
\hline Log likelihood & -920.0092 & & & 10.58839 \\
\hline F-statistic & 2.965977 & & & 1.429042 \\
\hline Prob(F-statistic) & 0.000101 & & & \\
\hline
\end{tabular}

Source: Author's Computation (2018)

From the table above for model 1, it was reported that main explanatory variable of AUDCOM and control variables except DEI showed a negative coefficient. In the table above, the AUDCOM revealed coefficient of 1.228820 with corresponding probability of 0.0141 . The result showed that our main variables of AUDCOM exert a negative and significant impact on financial performance measured in terms of ROE. Moreover, increasing the size of AUDCOM by one unit will lead to decrease in performance by -1.22820 . The $\mathrm{R}^{2}$ of 0.260470 implies that about $26 \%$ of the systematic variation in financial performance measured in terms of ROE is jointly explained by explanatory variables. The $\mathrm{P}$ - value $<0.05$ revealed significant joint impact of explanatory variables on financial performance. AUDCOM has significant impact on ROE at probability value of 0.0141 . 
Table 4.3 Regression Analysis for model 2

Dependent Variable: ROA

Method: Panel Least Squares

Date: 04/04/18 Time: 16:50

Sample: 20042015

Periods included: 12

Cross-sections included: 15

Total panel (balanced) observations: 180

White cross-section standard errors \& covariance (d.f. corrected)

WARNING: estimated coefficient covariance matrix is of reduced rank

\begin{tabular}{ccccr}
\hline \hline Variable & Coefficient & Std. Error & t-Statistic & Prob. \\
\hline \hline AUDCOM & -0.351431 & 0.174982 & -2.008378 & 0.0464 \\
BACT & -0.376311 & 0.338965 & -1.110176 & 0.2687 \\
BOS & -0.058382 & 0.083719 & -0.697355 & 0.4867 \\
CGDI & -0.003912 & 0.001999 & -1.957195 & 0.0522 \\
DEI & 0.145122 & 0.110255 & 1.316238 & 0.1901 \\
C & 76.18535 & 43.32908 & 1.758296 & 0.0808 \\
\hline \hline
\end{tabular}

Effects Specification

Cross-section fixed (dummy variables)

Period fixed (dummy variables)

\begin{tabular}{lrlr}
\hline \hline & 0.350784 & Mean dependent var & 6.638611 \\
Adjusted R-squared & 0.220069 & S.D. dependent var & 16.20316 \\
S.E. of regression & 14.30961 & Akaike info criterion & 8.315173 \\
Sum squared resid & 30509.97 & Schwarz criterion & 8.865072 \\
Log likelihood & -717.3656 & Hannan-Quinn criter. & 8.538133 \\
F-statistic & 2.683586 & Durbin-Watson stat & 1.246849 \\
Prob(F-statistic) & 0.000047 & &
\end{tabular}

Source: Author's Computation (2018)

The table above revealed that main independent variable of AUDCOM and control variables except DEI again showed a negative coefficient. The AUDCOM revealed coefficient of -0.351431 with corresponding probability of 0.0464 . The result showed that our main variables of AUDCOM exert a negative and significant impact on financial performance measured in terms of ROA. The result further revealed that an attempt to increase the size of AUDCOM by one unit will lead to decrease in performance by -0.351431 . The $\mathrm{R}^{2}$ of 0.350784 implies that about $35 \%$ of the variation in performance measured in terms of ROA is jointly explained by independent variables. The P- value $<0.05$ revealed significant joint impact of explanatory variables on financial performance. AUDCOM has significant effect on ROA at probability value of 0.0464 
Table 4.4 Regression Analysis for Model 3

Dependent Variable: TOBQ

Method: Panel EGLS (Cross-section weights)

Date: 04/04/18 Time: $16: 24$

Sample: 20042015

Periods included: 12

Cross-sections included: 15

Total panel (balanced) observations: 180

\begin{tabular}{crrrr}
\hline \hline Variable & Coefficient & Std. Error & t-Statistic & Prob. \\
\hline \hline CGDI & 0.206471 & 0.007627 & 27.06970 & 0.0000 \\
BOS & -0.992150 & 0.515113 & -1.926082 & 0.0559 \\
BACT & -0.050469 & 0.194839 & -0.259030 & 0.7959 \\
AUDCOM & -0.905279 & 0.417797 & -2.166794 & 0.0317 \\
DEI & 0.108734 & 0.268000 & 0.405723 & 0.6855 \\
C & 253.8445 & 61.57883 & 4.122269 & 0.0001 \\
\hline \hline
\end{tabular}

Effects Specification

Cross-section fixed (dummy variables)

\begin{tabular}{llll}
\hline \hline & \multicolumn{2}{l}{ Weighted Statistics } \\
\hline \hline R-squared & 0.592971 & Mean dependent var & 170.2375 \\
Adjusted R-squared & 0.544636 & S.D. dependent var & 159.9590 \\
S.E. of regression & 72.44884 & Sum squared resid & 839813.5 \\
F-statistic & 12.26802 & Durbin-Watson stat & 1.668004 \\
Prob(F-statistic) & 0.000000 & & 110.1866 \\
\hline \hline & Unweighted Statistics & 1.790629 \\
\hline \hline R-squared & \multirow{2}{*}{0.111304} & Mean dependent var \\
Sum squared resid & 886727.1 & Durbin-Watson stat & \\
\hline \hline
\end{tabular}

Source: Author's Computation (2018)

The table above for model 3 reported that AUDCOM and control variables except CGDI and DEI showed a negative coefficient. In the table above, the AUDCOM revealed coefficient of -0.905279 with corresponding probability of 0.0317 . The result showed a negative and significant relationship between AUDCOM and financial performance measured in terms of Tobin's Q Moreover, increasing the size of AUDCOM by one unit will lead to decrease in performance by -0.905279 . The $\mathrm{R}^{2}$ of 0.592971 implies that about $59 \%$ of the systematic variation in financial performance measured in terms of Tobin's Q is jointly explained by explanatory variables. The P- value $<0.05$ revealed significant joint impact of explanatory variables on financial performance. AUDCOM has significant impact on Tobin's $Q$ at probability value of 0.0317 .

\subsection{Summary and Conclusion}

Audit committee reveals significantly negative impact on performance measured in terms of return on equity, return on asset and Tobin's Q. This finding is in congruence with previous empirical studies of. Xie et al. (2003) and Bédard et al. (2004) that find negative association between audit committee size, measured by the number of directors on the committee, and performance management. This is also supported by the study of Abbott et al. (2004) that find negative relationship between audit committee size and reporting quality. The finding however, disagreed with the result of Abdul Rahman and Ali (2006) that reveals positive association between audit committee size and performance management. This indicates that a certain number of audit committee members may be vital to firm performance.

\subsubsection{Recommendation}

Since there is negative relationship between number of audit committee member and performance, it is necessary that the code of insurance corporate governance in Nigeria release by NAICOM look at compliance to other appropriate measure like competence (financial expert in committee) and independence of the committee that will ensure check and balance framework in the audit exercise and hence positive performance. 


\section{References}

Abbott, L. J. and S parker. (2000): Auditor Selection and Audit Committee Characteristics. Auditing: A Journal of practice \& Theory, pp 47-66.

Abbott, L. J., Park, Y and Parker, S (2000): The Effects of Audit Committee Activity and Independence on Corporate Fraud. Management Finance 26: 55-67.

Abdul Rahman, R., and Ali, F.H.M. (2006). Board, Audit Committee, Culture and Earnings Management: Malaysian Evidence. Managerial Auditing Journal, Vol. 21, No. 7: pp. 783-804.

Barnhart, S, Marr, M and Rosenstein, S (1994): 'Firm Performance and Board Composition: Some New Evidence ', Managerial and Decision Economics, vol. 15, no. 4, pp. 329-340.

Bedard, J., Chtourou, S.M., and Courteau, L. (2004). The Effect of Audit Committee Expertise, Independence and Activity on Aggressive Earnings Management. Auditing: A Journal of Practice \& Theory, Vol. 23: pp. 5579.

Beasley, M. (1996): 'An Empirical Analysis of the Relationship between the Board of Director Composition and Financial Statement Fraud', The Accounting Review, Vol. 71, No. 4, Pp.443-465.

Beasley, M., Carcello, J, Hermanson, D and Lapides, P.D (2000): Fraudulent Financial Reporting: Consideration of Industry Traits and Corporate Governance Mechanisms. Accounting Horizons, Pp 441-454.

Beasley, M., and. Petroni. K (2001): Board Independence and Audit Firm Type. Auditing: A Journal of practice and Theory, pp 97-114.

Berle, S.S \& Means, G.C (1932). The Modern Corporation and Private Property. New York, Macmillan.

Braiotta, L., and Zhou, J. (2006). An Exploratory Study of the Effects of the Sarbanes-Oxley Act, the SEC and United States Stock Exchange(s) Rules on Audit Committee Alignment. Managerial Auditing Journal, Vol. 21, No. 2: pp. 166-90.

Carcello, J., Hermanson, D.R, Neal, T.L and Riley, R. (2002): Board characteristics and audit fees. Contemporary Accounting Research (Fall), Pp 365-384.

Chen, K.Y., Lin, K.L., and Zhou, J. (2007). Audit Quality and Earnings Management for Taiwan IPO Firms. Managerial Auditing Journal, Vol. 20, No. 1: pp. 86-104.

Chiang, H. (2005): "An Empirical Study of Corporate Governance and Corporate Performance," The Journal of American Academy of Business, Cambridge 95-110

Collier, P., and A. Gregory. (1999): Audit committee activity and agency costs. Journal of Accounting and public Policy, 18, 311-332.

Dechow, P.M, Sloan, R.G and Sweeney, A.P (1996): Causes and consequences of earnings manipulation: An analysis of firms subject to enforcement actions by the SEC. Contemporary Accounting Research, Pp 1-36.

Dezoort, F.T and Salterio, S. (2001). The Effect of Corporate Governance Experience, Financial Reporting and Audit Knowledge of Audit Committee Member's Judgement, Auditing: A Journal of Practice and Theory, Vol. 20(2), Pp. 31-48

Donaldson, L. and Davis, J.H., (1991): Stewardship Theory or Agency Theory: CEO Governance and Shareholder Returns. Australian Journal of Management, Vol.16, Pp. 11- 19

Ebere, C.C and Ibanichuka, E.A (2016): Audit Committee and Financial Performance of Quoted Insurance Companies in Nigeria, International Journal of Advance Academic Research, Vol. 2, Pp 81-90

Fogarty, J. and Kalbers. L, (1998): Organizational and economic explanations of audit committee oversight. Journal of Managerial Issues 10(2): 129-150.

Freeman, R.E (1984), Strategic Management: A Stakeholder Approach, Cambridge University Press, New York.

Gales, L and Kesner, I (1994): 'An Analysis of Board of Director Size and Composition in Bankrupt Organizations', Journal of Business Research, vol. 30, pp. 271-82.

Haka, S. and Chalos, P. (1990): Evidence of agency conflict among management, auditors, and the audit committee chair. Journal of Accounting \& Public Policy,Pp 271-292.

Jensen, M., (1993): The Modern Industrial Revolution, Exit, and the Failure of Internal Control Systems, Journal of Finance, Vol.48, pp 831-840

Krishnamoorthy, G. (2002): A Multistage Approach to External Auditors' Evaluation of the Internal Audit Function. Auditing: A Journal of practice and Theory (March): 95-121.

Lipton, M. and. Lorsch, J.W (1992): A Modest Proposal for Improved Corporate Governance. Business Law Review, Vol. 48, No.1 Pp.59-77.

Mallin, C. (2004): The Relationship between Corporate Governance, Transparency and Financial Disclosure. International Review Journal Vol.10, No.4 pp. 253-255.

Menon, K., and Williams, J.D (1994): The use of audit committees for monitoring. Journal of Accounting and Public Policy, 13, 121-139.

Ntim, C. G., \& Osei, K. A. (2013). The impact of corporate board meetings on corporate performance in South Africa. African Review of Economics and Finance, 2(2), 83-103.

Olowookere, K (2014): Fundamentals of Auditing and Other Assurance Services, Aseda Publishing, Mapo Hill, 
Ibadan, Pp1-5

Pearce, J.A., and Zahra, S.A. (1992): Board Composition from a Strategic Contingency Perspective. Journal of Management Studies, Vol. 29, No. 4: pp. 411-438.

Smallman, C (2004): 'Exploring Theoretical Paradigm in Corporate Governance', International Journal of Business Governance and Ethics, vol. 1, no. 1, pp. 78-94.

Spence, M. (1973): “Job Market Signaling,” Quarterly Journal of Economics, 87(3), Pp 355-379.

Poitevin, M. (1990): “Strategic Financial Signaling,” Internal Journal of Industrial Organisation, 8(4), 499-518.

Ravid, S. A., and Sarig, O. H. (1991): "Financial Signalling by Committing to Cash Outflows," Journal of Financial and Quantitative Analysis, 26(2), 165-181.

Wild, J. J. (1996): The Audit Committee and Earnings Quality of Accounting. Auditing \& Finance 11: $247-276$.

Xie, B., Davidson, W., and DaDalt, P. (2003). Earnings Management and Corporate Governance: The Roles of the Board and the Audit Committee. Journal of Corporate Finance, Vol. 9, No. 3: pp. 295-317.

Yermack, D. (1996). Higher Valuation of Companies with a Small Board of Directors. Journal of Financial Economics, Vol. 40, No. 2: pp. 185-211. 